\title{
Mystagogy of Saint Nicholai Velimirovich
}

Pavle Botić

Faculty of Philosophy at the University of Novi Sad pavle.botic@ff.uns.ac.rs

Abstract: The present article is an effort to draw research, spiritual and prayerful attention to the spiritual mystagogy in the preaching, missionary and theological work of the Equal-to-the-Apostles Saint Nicholai Velimirovich of Ohrid and Žiča. As a preacher, missionary and theologian, God-bearing Bishop Nicholai in his mystagogy reveals to us that the Gospel of Christ means the possibility of healing and building the human soul for the Eternity of the Kingdom of the Most Holy Trinity.

Key words: Jesus Christ, Holy Gospel, Serbian Orthodox Church, Saint Nicholai Velimirovich, monastery, feat, repentance, mystagogy, enlightener.

\section{Тајноводство Светог Владике Николаја ${ }^{1}$}

Павле Ботић

Филозофски факултет, Универзитет у Новом Саду

Апстракт: Овај оглед је настојање да се скрене истраживачка, духовна и молитвена пажња на Духовдано тајноводство у проповедничком, мисионарском и богословском раду Равноапостолног Владике Николаја Охридског и Жичког. Тајноводство богоносног Владике Николаја открива нам да Јеванђеље Христово означа-

\footnotetext{
${ }^{1}$ Претходна верзија овог рада објављена је у Ботић 2020, 133-151.
} 
ва могућност исцељења и изграђивања човекове душе за Вечност Царства Свете Тројице.

Кључне речи: Исус Христос, Свето Јеванђеље, Српска Православна Црква, Свети Владика Николај, манастир, подвиг, покајање, тајноводство, просветитељ.

„Само кроз око Христово види се све како јесте, и на небу и на земљи, и у човеку, и у стварности. Зато ће и најтеже одговарати пред Богом они, којима је дано, да све гледају кроз Христово око, па не гледају.“

Свет̄и Николај Жички и Охрияски²

\section{I}

Свети Владика Николај Жички и Охридски у помесној Српској Православној Цркви, и у Свештеноме Православљу је други Свети Сава српски. Исповедник и Чудотворац, Проповедник и Богослов, Просветитељ и Исцелитељ, Свети Мисионар и Задужбинар, Пастир добри и Мученик, Владика Николај досеже висине покајања, правоверја и богопослушања Равноапостолнога Светога Саве српског.

Не постоји Свети Просветитељ из рода српскога који је од јеретичких народа, и од јеретичких Срба више гоњен и више клеветан од Песника Духа Светога, равноапостолнога Светог Николаја Жичког и Охридског! Духовдано тајноводство ${ }^{3}$ и правоверна проповед Христове науке Светога Владике Николаја су после Другог светског рата на земљи српској били гонитељима Српске Православне

\footnotetext{
2 Свети Николај Жички и Охридски 2001г, 112.

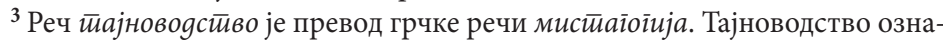
чава свештено упућивање, увођење у тајне Свейої Писма Духом Светим, саобразно апостолском Учењу Христове Цркве.
} 
Цркве већи „народни непријатељ“ и од апостолности богословља Светог Саве!

Благослов следовања свенародном просветитељу (обоженом, оцрквењеном и богопослушном српском монахумистйайоīy) који је Свети Сава Духом Светим завештао српскоме народу, напредна интелигенција српска образована без Образа Божијег није испунила. Противно завештању и вољи Светога Саве, Духовног Оца српскога народа, богохулна хуманистичка интелигенција српска је уместо Владике Николаја рукоположила у свенародног нововековног просветитеља српског, непокајаног раскалуђера, несветог просветитеља и најпознатијег српског јересеначалника, Доситеја Обрадовића!

Тако су обезбожени интелектуалци српски уместо светосавског Просветљења Духом Светим, заветном српском

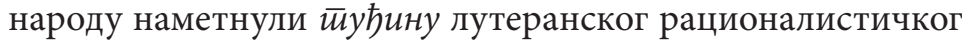
просвећења тамом људскога греха!

Ратујући против Богом усиновљенога Владике Николаја разбогаћена српска господа и злодуховна интелигенција српска, ратовали су против Светог Саве српскога, против Светих манастира и Светог монаштва, против Светих Отаца Христове Цркве, против Крста и Свештеног Предања, против Свет̄о̄ Јеванђеља и праве вере, против молитве и поста, против покајања и опраштања, против Заповести Блаженстава̂ и Девствености, против Боговаплоћења и Васкрсења.

Насупрот хамартизираној гносеологији, богочовечанско Учење Цркве од Истока сведочи да огњена со богословља Владике Николаја значи Благовест за српског и за сваког православног човека, јер је Владика Нико-

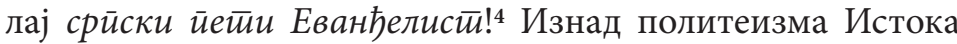

\footnotetext{
${ }^{4}$ Преподобни Јустин Ћелијски 1998а, 440. Отац Јустин потврђује да је појавом (тада јеромонаха) Николаја Велимировића у Београду, започео духовни земљотрес у српскоме народу, који ће трајати до Другог Доласка Господњег: „Од 1911. године, како се појавио у Београду, јеромонах, професор Богословије у Београду, Николај, од тада је започео духовни земљо-
} 
и материјализма Запада Свети Владика Николај проналази ипостасну Истину у Раgосној Вестии (у Јеванђеть, прим. П. Б.) Оваплоћенога Христа, Бога Православне Цркве. За Светог Владику Николаја Свештено Православље и није ништа друго до апостолска ${ }^{5}$ Вера у сваку Реч Господа Исуса Христа!6 До данас међу Светим Србима нема већег Учитеља Еванђељу Христовом од Светог Владике Николаја! $И$ нема у истиорији рода срйскоїа човека који је васкрсао више људских gуша оg Влаgике Николаја!

трес у српскоме народу, духовни земљотрес који је он изазвао и трајаће до Страшног Суда. Ко је тај Србин који је од 1911. године отишао ка Небу, пошао ка Господу Христу, а није се усудио и питао: Шта мисли јеромонах Николај? Како ово питање решава Владика Николај? Шта о томе мисли Епископ Жички Николај? Који је прави Србин ових педесет година, он зна да Православна Српска Црква није могла без Владике Николаја. Када се каже Српска Црква, у иностранству се мисли на Владику Николаја. Па и у Српској земљи, у мучној Српској земљи, када је душа хтела да крене ка Господу, тражила је њега за вођу, њега за путоказ.“ (Преподобни Јустин Ћелијски 1998а, 439).

5 Спаситељ Христос призива све људе да следују Њему и Јеванђељу: „Испунило се вријеме и приближило се Царство Божије; покајте се и вјерујте у Јеванђеље“ (Мк. 1, 42).

${ }^{6}$ Светоме Владики Николају Православље је једина богоносна Вера у Бесмртност Тројичног Бога и у бесмртност човекове личности: „Нема другог начина за људе да дођу до сазнања Истине у најглавнијим питањима живота и бића, него да приме на веру Речи Онога који је лични сведок небесних и духовних стварности. Или веровати Христу, или продужити лутати по мрачној и бурној пучини живота; лутати гатајући и слутећи о обалама и о земљи на крајевима те пучине. Треће није дато у историји људског мравињака до данашњег дана. Из тога је јасно, да хришћанска вера није ни налик на друге вере и друга веровања у свету. Јер друге су вере од људи са земље и од земље; од људи који су говорили о духовном свету или по своме природном разуму или по обмани злих духова. Нико од оснивача других вера није рекао за себе да је сишао с неба, ни да је послат од Оца, нити је да сведочи о небу оно што видје и чу, нити пак да се опет враћа на небо. Према томе, не може бити ни говора о сравњењу или изравнању између сведочанства Христова и осталих вера и веровања по беломе свету.“ (Свети Николај Жички и Охридски 20о1к, 478).

${ }^{7}$ Преподобни Јустин Ћелијски 1998ठ, 448.

${ }^{8}$ Преподобни Јустин Ћелијски 1998г, 459. 
Владика Николај час пребива у егзистенцијалном ужасу, час у молитвеном блаженству. ${ }^{9}$ Вративши се покајнички из туђине идолослужитељне Европе са два одбрањена доктората Једној, Светој, Саборној, Православној Цркви, Владика Николај је осетио сву испразност и сву неистинитост природног (телесног) сазнања, оног сазнања које се креће само у границама природе, противећи се ипостасној вери у Свету Тројицу. И зато је заменио хуманистич-

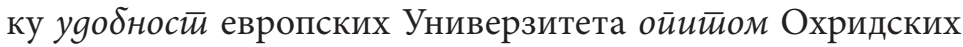
(манастир Калиште, манастир Светог Наума) и Светогорских пустиња̂. У подвигу манастирског домостроја покајања Владика Николај се окреће од твари према Творцу. Свети Владика Николај оставља грех и мртву веру, оставља празне речи мудрости људске и узима Крст свога спасења. Свети Владика Николај се сараспињао Крсту Христовом у непрестаној аскези, бдењу, молитви, посту, смирењу...

Богонадахнути Владика Николај је оправдао светињу манастира и одржао завет монаха, ${ }^{10}$ непрекидно исповедајући Небеско Царство Троличног Бога над собом, богообразну душу у човеку и Христово Јеванђеље као највеће вредности постојања сваког крштеног хришћанина.

Подвижнички постећи од мудрости овога света и од фарисејства теологије знања, Владика Николај Духом Светим би удостојен дара откривања духовних значења, Силе и Животворности Јеванђеља Богочовека Христа. Владика Николај није говорио од себе и није проповедао себе:

„Једно зрно вере у Христа вреди више него све огромно бреме знања о свему и свачему, само не о оном главном... Знање не спасава; вера спасава. А само је једна вера у свету,

${ }^{9}$ Преподобни Јустин Ћелијски 20о8, 16.

${ }^{10}$ Свети Николај Жички и Охридски 2016, 14. 
једна у историји човечанства. То је вера хришћанска. Све друго што се лажним именом назива вером, није вера, него ли знање, или полузнање, или гатање. Безбројна знања људи су досегли, али веру, једину праву веру Бог је донео човечанству. Знања се мењају, вера остаје. И европска и индијска знања сваки час могу се променити, али Христос и његова наука надживеће време и сву васиону. Једна је вера - Христова. Један је спас - Христос. Један је циљ Царство небесно. Један је Васкрситељ - Васкрсли Христос. Један је судија света - Он, увек исти и једини... Гомилање знања, по човеку и од човека, никад није дало ни топлоте ни светлости роду људскоме. “11

Духоносни Владика Николај устима признаје и срцем верује да се до циља човековог постојања, до Царства Небеског, не стиже знањем по човеку, већ живом вером у Вечноживога Господа, Исуса Христа. ${ }^{12}$ Јер, Христос Спаситељ има више заслуга за наш живот, и од наших телесних родитеља, пошто нас рађа за Вечност. ${ }^{13}$ Свети Владика Николај живом вером созерцава да знање не спасава душу људску од смрти (ср. 1. Кор. 8, 1). Душа човекова се од смрти, греха и ђавола не спасава чак ни знањем о Светој Тројици, већ примањем Воље Свете Тројице у себе! ${ }^{14}$

Христоумни Владика Николај је богопослан народу српскоме да виде који не виде, а да који виде постану слепи! ${ }^{15}$

\footnotetext{
11 Свети Николај Жички и Охридски 2001ј, 232.

12 „Јер ако исповиједаш устима својим да је Исус Господ, и вјерујеш у срцу својему да га Бог подиже из мртвих, бићеш спасен.“ (Рим. 10, 9).

${ }^{13}$ Ср. Свети Николај Жички и Охридски 20о1в, 100.

14 „У домостроју људскога спасења Отац има пуноћу дејства у свету, кад шаље Сина на дело спасења људског; Син има пуноћу дејства вршећи то дело спасења као Богочовек, а Дух Свети има пуноћу дејства утврђујући, освећујући и продужујући дело Сина.“ (Свети Николај Жички и Охридски 2001ж, 415).

${ }^{15}$ Отварајући телесне и духовне очи слепорођеноме, Богочовек Христос благовести: „За суд ја дођох у овај свијет, да виде који не виде, и који виде да постану слијепи.“ (Јн. 9, 39).
} 
Према тајноводству Светога Владике Николаја српски народ је од Господа призван да буде Теодул (Слуга Божији; народ Божији). И нико у Новом веку није толико Христом сагледавао, толико Христом будио, толико Христом трезнио, толиком Христом обухватио, толико Христом тајноводио српски народ као Свенародни Владика Николај. ${ }^{16}$

Живот и смрт, небо и земља, животиње и биље, врлина и грех, култура и религија, уметност и наука, прогрес и успех, вечност и време, добро и зло, здравље и болест, истина и лаж, историја и идеологија, мир и рат, здравље и болест, брак и монаштво, родитељи и деца, личност и заједница, Бог и ђаво у Рајској лествици тајноводства Светога Владике Николаја функционишу као јеванђелска и литургијска стварност!17 Владики Николају Христова Раgосна Вести, Христово Јеванђеље, значи могућност зидања човекове душе за Вечност у Небеском Јерусалиму.

Дело Светога Владике Николаја јесте йобеga Правоверја и залоі Духа, јер су речи тајноводства Владике Николаја речи Ума Христовог!18

\section{III}

Никоме од српских Светитеља није била дата толика тајноводствена сила разликовања телесних и духовних значења Светих јеванђелских парабола као Светоме Николају

\footnotetext{
16 Громовни Ава Јустин проповеда: „Нико није тако дубоко, тако свеобухватно, тако потресно захватио и обухватио српску историју, српског човека и Српски народ, као што је то Свети Владика Николај.“ (Преподобни Јустин Ћелијски 1998г, 456).

17 У љубостииғском сйослову Владика Николај пише: „Однос наш према Христу, Веснику Радосне Вести, одређује математички прецизно све друге наше односе према свима и свему!“ (Свети Николај Жички и Охридски 2001K, 481).

18 „Јер ко познаде ум Господњи да би га поучио? А ми имамо ум Христов.“ (1. Kop. 2, 16).
} 
Жичком и Охридском! ${ }^{19}$ Примајући Јеванђеље Христово првенствено као практичну науку, ${ }^{20}$ Свети Владика Николај је поред реалности дословних значења јеванђелских речи, имена̂ и приповести - следујући Светоме Григорију Богослову, Светоме Клименту Александријском, Светоме Кирилу Александријском, Светоме Јовану Дамаскину, Светоме Јовану Златоусту, Светоме Максиму Исповеднику, Светоме Симеону Новом Богослову, Светоме Григорију Палами, Светоме Игњатију Брјанчанинову - произносио и мистику символичних (духовних) значења Светйі Јеванђеља! Према епифанијским речима Светога Владике Николаја, за директно гледање истине духовне стварности без јеванђелских парабола (које је имао праотац Адам па изгубио, и које су апостоли изгубивши поново у Христу задобили), већина грехоиманих људи и није спремна, због помрачења органа видела грехом. ${ }^{21}$ Одебљала људска срца су грехом затворила очи свога ума који у срцу пребива, за јеванђелску словесност. ${ }^{22}$ Према духовном искуству Владике Николаја, Светио Писмо Божије не открива човеку било какву појмовну, времено-вечносну философију суштине бића и ствари, већ благовести спасоносну силу временог и вечносног значењ а бића и ствари. ${ }^{23}$ Зато су на првом месту Омилије Владике Николаја неопходно Тајноводство

19 За Преподобног Јустина Ћелијског Свети Владика Николај је јединствени васкрситељ душа српских, које су од његове целебне речи прогледале Јеванђелем: „Нико није као он отворио очи Српскоме народу и српскоме човеку да прогледа!“ (Преподобни Јустин Ћелијски 1998в, 452).

20 „Основна разлика пак између источне и западне Цркве од велике шизме 1054. до данас састоји се у различитом схватању Јеванђељь Христова. Запад је у том времену, а и нешто пре тога почео схватати Јеванђеље као теорију, а потом и као једну од многих теорија о свету и животу, док је Исток схватио Јеванђеље као подвиг и праксу. Отуда је дошло, да је Догматика на Западу постала чисто теоријска наука т. ј. једна од многих философија, док је на Истоку била и остала до данашњег дана практична наука.“ (Свети Николај Жички и Охридски, 2001к, 482-483).

${ }^{21}$ Ср. Свети Николај Жички и Охридски 20о1и, 115.

22 Свети Николај Жички и Охридски 2о01и, 114.

23 Свети Николај Охридски и Жички 20о1и, 144. 
за литургијски живот по Јеванђељу, јер Духом Светим исцељују човечије органе богопознања. А тек исцељени органи богопознања (срце, воља и ум) задобијају својства божанске писмености: да гледајући виде и да слушајући чују нерукойворена значень јеванђелских прича.

Тумачећи смисао неопходности Господњих говора у причама и именујући мистику значења десетога стиха осме главе Свейоїа Јеванђеља йо Луки („Вама је дано да знате тајне Царства Божијега, а осталима бива у причама, да гледајући не виде, и чујући не разумију“) Свети Владика Николај тајноводи речима Ума Христовог:

„А да се и апостолима није могло увек говорити без прича, види се из Христовог последњег говора њима: ово вам іоворим у иричама, али ће gоћи време каg вам више нећу іоворийи у ирричама (Јн. 16, 25). А зашто народу говори у причама? Да ілеgајући не виgе, и слушајући не разумеју. То јест: кад би им говорио управо, и без прича, они би гледали телесним очима и не би видели ништа, и слушали би телесним ушима и не би разумели ништа. Јер духовне ствари се не виде телесним очима, нити се чују телесним ушима. А да ове речи имају тај смисао, јасно је из нешто друкчије изречене те исте реченице код Матеја - јер гледајући не виде, и слушајући не чују нити разумеју. То јест: кад им Господ говори духовне истине наге, без одела прича и сравњења са стварима и догађајима из овога чулног света, они не виде те истине, они их не чују, нити разумеју. Све духовне истине су из онога света - из света духовнога, небеснога - и само се духовним видом и слухом и разумом могу запазити и појмити. Но, те духовне истине су изложене у овоме свету под оделом ствари и догађаја. Код многих људи изгубљен је вид и слух и разум за духовне истине. Многи гледају само одело, и слушају само спољашњи глас, и разумеју само спољашња својства и облике и природу ствари и догађаја. То је телесни вид, телесни слух, и телес- 
ни разум. Господ Исус је познао слепило људи, и зато као премудри Учитељ руководи људе од телесних предмета ка духовним. Зато им говори у причама, то јест у оном облику који је једино доступан њиховом виду, слуху и разуму. ${ }^{24}$

Владика Николај је први међу нововековним српским Светитељима свим срцем својим, свом душом својим, свим умом својим, сваком речју својом и сваким словом својим сведочио разлику између привида̂ телесне побожности и Духовданог апостолског правоверја (православља, благочестија). Јер, Дух Свети оживљава, а телесни ум ништа не користи (Јн. 6, 63). Владика Николај указује да православни хришћани не треба да се обазиру на телесну теологију идолопоклоника̂ (великаша̂, хуманиста̂, доктора̂ наука̂ пале људске природе), јер сви они скупа Светио Јеванђелье сазнају и проповедају страстима ума! ${ }^{25}$ Према богоносном сведочанству Владике Николаја скривени смисао свих јеванђелских парабола налази се само у области Духа, у Царству Тројичне стварности, која се сагледава блаженим видом чистог човечијег срца (Мт. 5, 8). ${ }^{26}$ Речју, мистерије значења Свейоїа Јеванђеља за све Свете Христове Богослове, и за Владику Николаја, откривају се поступно, прозрачним срцем у Духу Светоме. ${ }^{27}$

Тајноводство Светога Владике Николаја Духом Светим открива крштеном хришћанском човеку тајну Спаситељевог ипостасног присуства у Великом входу свих јеванђелских прича, дарујући хришћанину могућност јеванђелског кретања од телесног ка духовном значењу Тројичног Бога и

24 Свети Николај Жички и Охридски 2001ђ, 239.

25 Свети Николај Жички и Охридски 2001г, 115.

26 у Омилији на Јеванђеље о чист̄отии ума, Владика Николај се позива на богомудро разликовање духова Првоврховнога Апостола Павла:

„А тјелесни човјек не прима што је од Духа Божијега, јер му је лудост, и не може да разумије, јер се то испитује духовно. Духовни пак све испитује, а њега самог нико не испитује.“ (1. Кор. 2, 14-15).

27 Свети Николај Жички и Охридски 2001г, 114-115. 
човека, ада и ђавола, новозаветних речи и символа, тропа и фигура, прича и личности. Владика Николај подсећа да су Светиа Јеванђеља записали Свети Божији људи, надахнути божанском Силом Духа Светога. Богоносни Јеванђелисти (Матеј, Марко, Лука и Јован) су живећи у времену уз Оваплоћеног Господа, и следујући Светој Речи Господњој, заправо пребивали у благодатном, подвижничком стању. Да би мистична значења јеванђелске реалности била примана, неопходно је да крштени, писмени и омолитвљени причасник Свештеним Јеванђељем буде у опитном стању покајања руковођен Светим Тајнама Цркве. Насупрот земљи која даје брзе плодове, плодови са чокота Речи Божије траже себеостављајућу трпељивост и стрпљење! ${ }^{28} \mathrm{~A}$ Господ ће само душу приведену Јеванђељь, одвести у нерукотворени, небески Јерусалим!

\section{IV}

Омилије Владике Николаја доказују да само јеванђелске параболе од свих постојећих писаних и усмених парабола од људи створених у свима световима и временима, у себи носе тајну човекове победе над сопственом палом природом помоћу Бога. Пошто је сав људски род обузет болешћу пада у грех, онда се такво стање општег грехопада може назвати природним стањем свеукупног рода људског. ${ }^{29} \mathrm{~A}$ једино јеванђелске приче садрже тајноводствену методику човековог ослобађања од детерминизма природе грехопалог телесног човека, који - према речима Владике Николаја - непрестано ратује против духовног човека. Раgосне

\footnotetext{
${ }^{28}$ Свети Владика Николај 2001ђ), 240.

29 „Стање пада, у коме се данас налази читав људски род, то је стање неприродно, подприродно и противприрпдно. Али пошто је читав људски род обузет недугом пада, онда се то стање општег недуга може назвати природним палом људском роду.“ (Свети Игњатије Брјанчанинов 2017, 388).
} 
Вестии Новоїа Заветиа о Светој Тројици, о бесеменом зачећу Духом Светим, о Вечној Девствености Пресвете Богородице, о Оваплоћењу Бога, о власништву Бога над човеком, о Очевој Христовој Науци, о ипостасној Истини, о саможртвеној љубави, о блаженом духовном сиромаштву, о оцу лажи, о греху смеха, о љубави према непријатеља, о мржњи према телесним сродницима, о првима и последњима, о безумљу људске мудрости, о лудости Крста, о Христовим овцама које побеђују вукове, о ходању по води, о бесловесности многобрижја, о остављању себе и следовању Христу, о благослову страдања, о безумљу богаташа, о Сејачу и семену, о Цркви која је Тело Христово, о Царству Небеском, о Васкрсној смрти Христовој, о Вазнесењу Христовом, о Другом Доласку Христовом... су природним (телесним) хришћанима нерадосне и недоступне. Благовести Христове Науке природним хришћанима делују нелогично, противприродно и противречно!

Према суду Владике Николаја Дух Свети истине и тајне Јеванђеља не открива подједнако свима члановима Цркве, јер се чланови Цркве међусобно разликују по ревности у вери. А само у Pagocној Вестии Богочовека који је ипостасна Истина, ${ }^{30}$ не може бити ни значењске, ни личносне противречности, јер у Богочовеку нема ни греха, ни смрти! Зачета у безакоњу архистратига зла, противречност се пројављује кроз беспоредак човековог самооикривења!

Дејством Духа Светога ослобођен од тираније противречности, од злодуха времена и од конформизма прелести, Владика Николај показује сву новост и нечитљивост, разликовност и логосност, несавременост и ирационалност, надприродност и животворност духовних значења Нової Завейа!

А за усиновљену децу Божију Раgосна Вести Христова јесте једина храна, једини лек, једини смисао и једини циљ.

30 „Речено је још, да је Бог Истина и Слово. Чудесна је то реч словенска - Истина - која савршено означава Онога који је увек исти.“" (Свети Николај Жички и Охридски 2001л, 507). 
Благодарном малом стаду Божијем моћ светитељског тајноводства открива да Јеванђетье доноси Оваплоћену Милост и Правду:

„Од створења васионе никад нико није поставио тако велике и страшне разлике између човека и човека као Јеванђеље. Једни су људи названи синови светлости, а други синови таме. Једни су признали Бога за Оца, а други ђавола. Једни су обележени као синови Царства, а други као синови пакла. Једни су уз Христа, други уз Антихриста. Кроз једне дејствује Дух Истине, а кроз друге духови лажи. “"11

Наведене апостолске речи Светога Владике Николаја дешифрују дејства и именују тајанствена својства Светио Јеванђеља. Бесмртно и страшно Јеванђеље Христово је сласт и горчина. Спасоносна Раgосна Весй Христова исцељује и кажњава, усиновљује и осуђује, низводи аду или узноси Царству Божијем. Ниједној души људској није могуће избећи суд Јеванђеть, јер Логос Очев стоји на почетку свих почетака, ${ }^{32}$ приводећи из небића у биће све постојеће душе. ${ }^{33}$ Јеванђелско видело указује да нема ничег случајног под Сунцем: све што постоји промислитељно постоји Богом Логосом. Мач Спаситељеве Милости и Правде непогрешиво разликује и раздваја, ${ }^{34}$ дајући свима људима да по слободи своје воље служе Богочовеку или Велијару.

Према обоженом слову Омилија Владике Николаја устанак хришћанина против природе телесних значења, те-

\footnotetext{
31 Свети Николај Жички и Охридски 2о01к, 486.

32 „У почетку беше Логос, и Логос бјеше у Бога, и Логос бјеше Бог.“ (Јн. 1, 1).

33 „Све кроз Њега постаде, и без Њега ништа не постаде што је постало.“ (JH. 1, 3).

34 „Не мислите да сам дошао да донесем мир на земљу; нисам дошао да донесем мир, него мач. Јер сам дошао да раставим човјека од оца његовог и кћер од матере њезине и снаху од свекрве њезине." (Мт. 10, 34-35).
} 
лесне љубави, телесних дела, телесних тежњи, телесне истине, телесне мудрости, телесне слободе, телесног живота, телесне заједнице, телесне науке, телесног прогреса, телесног добра, телесног завета, телесног поста, телесне молитве, телесне вере, раван је подвигу апостолског ходања по води:

„И изишавши из лађе Петар иђаше по води да дође к Исусу. Док је имао вере, дотле је Петар и ходио по води, но чим је освојила сумња он је почео тонути. Јер сумња изазива страх. По унутрашњем смислу изаћи из лађе и ићи по води ка Господу Исусу значи одвојити се својом душом од тела, и од брига телесних, и љубави телесне, и почети ходити опасном стазом ка духовном свету, ка Спаситељу. Ти тренуци бивају и код обичних верних, код маловерних, код којих је радост у Христу помешана са сумњом. Они често пожеле да се одвоје од своје телесне вреће, и да пођу ка Христу, Цару духовног света, но брзо осете да тону, те се враћају ка своме телу, као лађи на таласима. Само велики духовници, највећи јунаци у човечанству, успевали су дугим вежбањем у постојаности вере, да се крену из своје телесне лађе по бурноме мору духовноме у сретање Цару Христу. И само су они до краја испитали и страх од тог одвајања од лађе, и ужас од бура и ветрова, и неописану радост од сретања са Христом. То одвајање духом од лађе тела искусио је за живота на земљи апостол Павле - и многи други Светитељи после њега. Каква је радост и сласт била на крају опаснога пута за великог апостола, види се из његовог радосног усклика: Таквим ћу се хвалитии! (2. Кор. 12, 5).“"35

По богомудрој Омилији Владике Николаја на Јеванђеље о Jачем og йрироgе (надахнуте тајноводственом Посланицом

35 Свети Николај Жички и Охридски 2001д, 155. 
Галайима Првоврховнога Апостола Павла) човеков излазак из природног стања зависи од делатне љубави човекове вере. ${ }^{36}$ Господ прима веру која дела кроз љубав богопослушања: Ко има зайовијестии моје и gржи их, йо је онај који ме љуби (Јов. 14, 21)! Жива (апостолска) вера у Христово Јеванђеље укључује ангажовање свеколиког човековог бића у рату против сопствене природе, јер, йрироgа йосиаје ярвейом искушења за човека! ${ }^{37}$ А стање човекове природе после прародитељског пада у грех јесте огреховљеност. Исцељење рода људског од сопствене грешне природе и од смрти, није могуће без Безгрешног Богочовека и Цркве Његове. Постојаност живе вере у Вечно Живог, Оваплоћеног и Васкрслог Богочовека открива се у опиту чишћења човековог срца, воље и ума од греха, животом по Светој Вољи Господњој..$^{38}$

Кретање узином и йеснином ${ }^{39}$ држања јеванђелских заповести није лишено искушења, страдања, жртве и муке. Зато нас Црква од Истока теши и храни, очишћује и обесмрћује реализмом Божанствене Литургије! ${ }^{40}$

36 „Јер у Христу Исусу нити што вриједи обрезање или необрезање, него вјера која кроз љубав дјела.“ (Гал. 5, 6).

37 Свети Владика Николај 2о01а, 9.

${ }^{38}$ Као пример савршеног послушања Спаситељу Христу које надилази Светост послуха свих Светих Христових, Владика Николај наводи Личност Пресвете Богородице, која пред архангелом Гаврилом исповеда: Ево слушкиюе Госйоgюе - нека ми бyge йо Ријечи йвојој! (Лк. 1, 38). Владика Николај просвећује: „Од гордости и непослушности онечистило се срце Евино и помрачио ум њен, од гордости и непослушности наспрам Бога пропао је стари свет, онаказио се род људски, унесрећила се сва створена твар. На смирењу и послушности има се зидати нови свет. Неописиво је смирење и послушност Пресвете Богомајке, њу ће само њен Син, Спаситељ и Обновитељ свеколике твари, превазићи Својим бескрајним смирењем и послушношћу.“ (Свети Николај Охридски и Жички 2001a, 14).

39 у Бесеgи на Гори Спаситељ проповеда узак пут и тесна врата који воде у Живот Вечни:

„Уђите на уска врата; јер су широка врата и широк пут што воде у пропаст, и много их има који њиме иду. Јер су уска врата и тијесан пут што воде у живот, и мало их је који га налазе.“ (Мт. 7, 13-14).

40 Свети Николај Жички и Охридски 2001j, 310-316. 
Из Омилије Владике Николаја на Јеванђеље о Јачем og природе, видимо да човековим пасхалним преласком из природности греховног стања у покајно стање богоопштења (које је обновљена боголикост првобитног прародитељског битија пре пада), хришћанин Духом Светим задобија животворне силе да хода по води своје греховођене смртне природе! Верујуће разапињање страсне природе сопственог бића, равно је подвигу бескрвног страдања за Христа! Јер, вера корача изнаg йрироgе! ${ }^{41}$ Само живом вером у Христово развлашћење смрти, задобијамо богочовечанску силу личносног превазилажења природности греха и неопходности смрти. У подвигу живе вере умиру састојци греха природног човека, зарад поновног рођења духовног човека, али овога пута у Духу Светоме! У свакој својој Омилији Владика Николај сведочи да за Богочовека не важе закони природе, и да логика или закони природних значења̂ не важе у домостроју пријема благодатних значења̂ Свет̄о一̄a Јеванђетьа.

Већ у времену, промислитељно тајноводство Светога Владике Николаја доноси милост христообразног хођена вером (2. Кор. 5, 7) и једнодушног примања Христове Рagocне Весйu!

\section{$\dagger \dagger \dagger$}

У Цркви Христовој не могу сви да поучавају. ${ }^{42}$

Дела тајноводства носе унутрашњу посвећеност Спаситељу и трежњење покајне душе људске. Зато се, према речима Владике Николаја, Светим тајноводственицима (мистагозима) Духом Светим открива више јеванђелских тајни и истина̂, него што је Господ открио и самим апостолима! ${ }^{43}$

41 Преподобни Јустин Ћелијски 1999, 175.

42 Јеромонах Рафаило Бољевић 2015, 41, 21.

43 Свети Николај Жички и Охридски 2001к, 489. 
Духом Светим усиновљени Свети Владика Николај Жички и Охридски открива да Пут човековог спасења од греха, смрти и ђавола почива у Православној вери, која кроз љубав послушања Светом Христовом Јеванђељу и Цркви Његовој, дела. Владика Николај просвећује: човек је својина Тројичнога Бога, ${ }^{44}$ јер нико није жив од имовине своје (Лк. 12, 15), већ од Бога у себи. А Владика Николај је даноноћно раздавао јеgино йойребно: христоумне речи тајноводства кроз Свейо Јеванђелье, како би сви ми, прелашћени хришћани, коначно задобили благо Богом богато и како би задобили срце на небесима (Мт. 6, 21)!

Не могу ни ђаволи, ни ђавовођени људи отети Светога Владику Николаја од Троличног Бога и од малог стада народа Божијег. ${ }^{45}$

И после кончине тела Светога Владике Николаја, његове речи Христовог Ума, васкрсавају смртоимане душе Силом Раgосне Вестии.

\footnotetext{
44 Свети Николај Жички и Охридски 2001е, 244.

45 Потресна и дирљива Беседа Владике Николаја О Христиовој мағини, изговорена на Велики Петак у Саборном храму у Пожаревцу, оваплоћује плач малог стада Христовог за Распетим својим Господом: „Под самим крстом стајала је једна жена, која је рукама обујмила крст и ноге Христове, и пољупцима и сузама трудила се да олакша бол распетоме. То је била Мајка. До ње је стајао један млад човек, који је са најдубљим учешћем пратио сваки болни покрет Мученика на крсту и овде-онде придржавао несрећну мајку и шаптао јој речи утехе. То је био једини неустрашиви Пријатељ. Мало даље од мајке и Пријатеља, стајале су две три жене, које су биле скрушене од исте жалости, која је скрушавала и Мајку и Пријатеља под крстом. То мало друштво од 5-6 особа сачињавало је ону мањину, која није очекивала с нестрпљењем ни смрт Христову, нити какво чудо од Њега и која није осећала никакву глад другу, до безнадежну глад за тим, да се Распетоме Праведнику ма како, и ма и по цену свог сопственог живота и ма колико једна кап хладне воде са извора Јордана, олакша бол и страдање.“ (Свети Владика Николај 2о013, 467).
} 


\section{Библиографија}

\section{Извори}

Светио Писмо: Нови Завјети Госйоgа нашеї Исуса Христйа. 1998. Превод Комисије Светог Архијерејског Синода СПЦ, 4. исправљено издање. Београд: Свети Архијерејски Синод Српске Православне Цркве.

[Велимировић,] Николај, Свети Жички и Охридски. $2001 \mathrm{a}$ „Благовести (Јеванђеље архистратига Гаврила)“. У Омилије, Сабрана gела, II, 7-14. Линц - СПЦО Линц, Аустрија.

[Велимировић,] Николај, Свети Жички и Охридски. 20016. „Јеванђеље о Страшном Суду“. У Омилије, Сабрана gела, II, 849о. Линц - СПЦО Линц, Аустрија.

[Велимировић,] Николај, Свети Жички и Охридски. 20о1в. „Јеванђеље о следовању Христу“. У Омилије, Сабрана gела, II, 98-104. Линц - СПЦО Линц, Аустрија.

[Велимировић,] Николај, Свети Жички и Охридски. 2001г. „Јеванђеље о чистоти ума“. У Омилије, Сабрана gела, II, 110-116. Линц - СПЦО Линц, Аустрија.

[Велимировић,] Николај, Свети Жички и Охридски. 2о01д. „Јеванђеље о Јачем од природе“. У Омилије, Сабрана gела, II, 150157. Линц - СПЦО Линц, Аустрија.

[Велимировић,] Николај, Свети Жички и Охридски. 2001ђ. „Јеванђеље о Господу Сејачу“. У Омилије, Сабрана gела, II, 236242. Линц - СПЦО Линц, Аустрија.

[Велимировић,] Николај, Свети Жички и Охридски. 2001е. „Јеванђеље о Лазару и богаташу“. У Омилије, Сабрана gела, II, 243-251. Линц - СПЦО Линц, Аустрија.

[Велимировић,] Николај, Свети Жички и Охридски. 2оо1ж. „Духовдан (Јеванђеље о силаску Духа Светога)“. У Омилије, Сабрана gела, II, 412-418. Линц - СПЦО Линц, Аустрија.

[Велимировић,] Николај, Свети Жички и Охридски. 20013. „О Христовој мањини“. У Омилије, Сабрана gела, II, 466-475. Линц - СПЦО Линц, Аустрија. 
[Велимировић,] Николај, Свети Жички и Охридски. $2001 и$. Символи и сиінали. У Сабрана gела, V, 113-144. Линц - СПЦО Линц, Аустрија.

[Велимировић,] Николај, Свети Жички и Охридски. 20о1ј. Теоgул. У Сабрана gела, V, 193-317. Линц - СПЦО Линц, Аустрија.

[Велимировић,] Николај, Свети Жички и Охридски. 20о1к. „Љубостињски стослов“. У Сабрана gела, V, 477-492. Линц СПЦО Линц, Аустрија.

[Велимировић,] Николај, Свети Жички и Охридски. $2001 л$. Касијана. У Сабрана gела, V, 495-525. Линц - СПЦО Линц, Аустрија.

[Велимировић,] Николај, Свети Жички и Охридски. 2016. Војловички стиослов. Будва: Манастир Подмаине.

\section{Литература}

Бољевић, Рафаило, јеромонах. 2015. „Промоција издања Манастира Подмаине у сали Матице српске у Подгорици“; цитирано према https://manastirpodmaine.org/predavanje/ promocija-izdanja-manastira-podmaine-u-sali-matice-srpske/ / www.manastirpodmaine.org, 24. 04. 2015, 41, 21.

Ботић, Павле. 2020. Дух јеgномислија (Тумачене јеванђелске стиварностии). Нови Сад: Писменик.

Игњатије Брјанчанинов, Свети. 2017. „Излагање учења Православне Цркве о Мајци Божијој“. У Аскейске йройовеgu, 371403. Библиотека „Очев дом“, коло 3, књ. 23. Превео Младен Станковић. Београд: Верско добротворно старатељство Архиепископије београдско-карловачке - Православна мисионарска школа при Храму Светог Александра Невског.

[Поповић,] Јустин, Преподобни Ћелијски. 1998а. „Беседа 1. на парастосу Владици Николају“. у Бесеgе Прейоgобной Оиа Јустиина (Ћелијскоі). Том 1: Празничне бесеgе, 437-442. Сабрана дела Светог Јустина Новог у 30 књига; књ. 1. Београд Ваљево: Наследници Оца Јустина - Манастир Ћелије.

[Поповић,] Јустин, Преподобни Ћелијски. 1998б. „Беседа 2. на парастосу Владици Николају“. у Бесеgе Прейоgобноі Оuза 
Јустиина (Ћелијской). Том 1: Празничне бесеgе, 443-449. Сабрана дела Светог Јустина Новог у 30 књига; књ. 1. Београд Ваљево: Наследници Оца Јустина - Манастир Ћелије.

[Поповић,] Јустин, Преподобни Ћелијски. 1998в. „Беседа 3. на парастосу Владици Николају“. У Бесеgе Прейоgобної Оuза Јустиина (Ћелијскої). Том 1: Празничне бесеgе, 450-455. Сабрана дела Светог Јустина Новог у 30 књига; књ. 1. Београд Ваљево: Наследници Оца Јустина - Манастир Ћелије.

[Поповић,] Јустин, Преподобни Ћелијски. 1998г. „Беседа 4. на парастосу Владици Николају“. У Бесеgе Прейоgобної Ойа Јустиина (Ћелијскої). Том 1: Празничне бесеgе, 456-462. Сабрана дела Светог Јустина Новог у зо књига; књ. 1. Београд Ваљево: Наследници Оца Јустина - Манастир Ћелије.

[Поповић,] Јустин, Преподобни Ћелијски. 1998д. „Беседа 5. на парастосу Владици Николају“. У Бесеgе Прейоgобної Оияа Јустиина (Ћелијскоі). Том 1: Празничне бесеgе, 463-468. Сабрана дела Светог Јустина Новог у 30 књига; књ. 1. Београд Ваљево: Наследници Оца Јустина - Манастир Ћелије.

[Поповић,] Јустин, Преподобни Ћелијски. 1999. „Тајна сазнања“. У Пуй бойойознаюа. Философске урвине, 173-184. Сабрана дела Светог Јустина Новог у зо књига; књ. 8-9. Београд - Ваљево: Наследници Оца Јустина - Манастир Ћелије.

[Поповић,] Јустин, Преподобни Ћелијски. 2008. „Епископ Охридски Николај: Мисли о gобру и злу“. У Сейве и жетиве: чланци и мағи ситиси, 716-721. Сабрана дела Светог Јустина Новог у зо књига; књ. 20. Београд - Ваљево: Наследници Оца Јустина - Манастир Ћелије. 